\title{
The Differences between Thai and Indonesian Undergraduates in Pronouncing Plural Nouns and Third Singular Present
} Verbs due to Progressive Assimilation

\section{Sofa Zakiyatul Muna}

English Department of Educational Faculty Institut Agama Islam Negeri (IAIN) Salatiga JI. Tentara Pelajar No.02 Salatiga, Central Java, Indonesia shovazakia84@gmail.com

\begin{abstract}
Pronunciation is an important aspect in learning English and it is varied in different area. There are several types of dialect differences in speaking English and geographical dialect is one of them. In pronouncing plural verbs and third singular present verbs in English, the differences are happened. This research investigates the differences between Thai and Indonesian undergraduates in pronouncing plural nouns and third singular present verbs with $\mathrm{s} / \mathrm{es}$ ending. The aim of this research are to find out the differences and similarities between Thai and Indonesian undergraduates in pronouncing plural nouns and third singular present verbs and the factors that influence it. The design of this research is case study by investigating Thai and Indonesian undergraduates of IAIN Salatiga in several period of time. Data is collected through documentation and interview. Documentation is conducted by recording respondents' pronunciation. The recording is analyzed and combined with interview report to answer research problems. From the analysis, it is found that the differences and similarities of Thai and Indonesian undergraduates are substitution and omission of s/es suffix pronunciation. It is influenced by the geographic dialects and the existence of consonants in native language.
\end{abstract}


Keywords : plural noun and third singular present verbs, progressive assimilation, case study.

\begin{abstract}
Abstrak
Pronunciation merupakan suatu aspek penting dalam pembelajaran Bahasa Inggris yang bervariasi di berbagai daerah. Ada beberapa tipe perbedaan dialek dalam berbicara Bahasa Inggris, salah satunya adalah dialek geografis. Perbedaan dalam pelafalan bahasa Inggris diantaranya terjadi dalam pelafalan plural nouns(kata benda jamak) dan third singular present verbs (kata kerja bentuk present orang ketiga tunggal) dalam bahasa inggris. Riset ini bertujuan untuk meneliti perbedaan dan persamaan antara mahasiswa Thailand dan Indonesia dalam melafalkan plural nouns dan third singular present verbs serta fakfor-faktor yang mempengaruhinya. Penelitian ini merupakan studi kasus dengan meneliti mahasiswa Thailand dan Indonesia di IAIN Salatiga dalam jangka beberapa waktu. Data dikumpulkan melalui dokumentasi dan wawancara. Dokumentasi dilakukan dengan cara merekam pronunciation para responden. Hasil rekaman dianalisis dan dipadukan dengan hasil interview untuk menjawab rumusan masalah. Dari hasil analisis, ditemukan bahwa perbedaan dan persamaan mahasiswa Thailand dan Indonesia dalam pelafalan kata benda jamak dan kata kerja present orang ketiga tunggal dengan akhiran s/es penggantian dan penghilangan pelafalan akhiran s/es. Hal ini dipengaruhi oleh dialek geografis dan keberadaan konsonan dalam bahasa asli.

Kata Kunci: kata benda jamak, kata kerja present orang ketiga tunggal, asimilasi progresif, studi kasus.
\end{abstract}

\title{
Introduction
}

Pronunciation is an important aspect in learning English. We have to be able to speak it properly as native speak it. In English, there are two studies of linguistics which deal with sound, namely phonetics and phonology (McMahon, 2002:1). Although pronunciation is an important matter, it cannot be expected to be homogenous and it is natural that it varies in time and places. It does not matter as long as the language understandable. Because people have different mother tongue which automatically set their speech organ to produce the sound, it can be 
understood that they find difficulties in pronouncing foreign language, in this case English. Other factors that influence the differences of pronunciation are geographic, social, historical factors and individual peculiarities.

People often pronounce plural nouns and third singular verbs in daily conversation. In English grammar, the general rules of plural noun and third singular verbs should be added by s/es (Frank, 1972:3). Beside grammar, English learners have to consider phonetic rule of s/es pronunciation. According to Hamann and Schmitz, the general rule of the pronunciation is it can be pronounced with three forms, those are $/ \mathrm{s} /, / \mathrm{z} /$ and /IZ/ (2005:52). Sometimes students and undergraduates get difficulties in pronouncing words ended with s/es such in plural form and present verb correctly. The common mistakes are substituting the "s" sound where the " $\mathrm{z}$ " should be, some words that should be spelled with an "s" sound but pronounced with "z" sound. They also do not spell the /iz/ sound properly.

Pronunciation problem is also faced by the students in IAIN Salatiga. They do not pay attention to the pronunciation of $-\mathrm{s}$ or $-\mathrm{es}$ ending. They ignore the phonological rule of these suffixes in different words. They only apply the same rule for every word ended with $-\mathrm{s}$ or -es, adding the sound " $\mathrm{s}$ " in the end of the word without knowing the phonological rules. They do not recognize when they have to use " $z$ " sound or "iz" sound. This problem is not only faced by Indonesian undergraduates, but also Thai undergraduates since in 2014 there are several Thai undergraduates in IAIN Salatiga. The writer is interested to conduct a research based on this phenomena so in can help the undergraduates to pronounce the words properly by understanding the 
pronunciation rule.

\section{Progressive Assimilation}

In English phonetics and phonology, we can find many connected speech phenomena and it is usually described in terms of some kind of process or change. One of these phenomena is assimilation. Ramelan (2004:172) defines assimilation as the process in which one phoneme is replaced by another phoneme as the result of combining one morpheme with another. Meanwhile, in the glossary of phonetic term by Lodge (2009:226), assimilation is a term that refers to cases where there are alternative pronunciations of the same lexical item and where a phonetic feature is shared by a number of contiguous syllable places, for example, place of articulation, nasality. There will be various sound of a lexical item because it is influenced by its surrounding sound of the lexical item.

According to Roach (2000: 124), there are two kinds of assimilation, regressive and progressive assimilation. Progressive assimilation is the alteration that occurs when the phoneme is affected by one that comes earlier in the utterance. One example of progressive assimilation is the assimilation of voice with the suffixes /s/ and /z/ when the verb carries third person singular $-\mathrm{s}$ suffix, or a noun carries an $-\mathrm{s}$ plural suffix or an - s possessive suffix, that suffix will be pronounced as $\mathrm{s}$ if the preceding consonant is voiceless and $\mathrm{z}$ if the preceding consonant is voiced. Lorenz (2009:17) calls this kind of assimilation with grammaticalized assimilation. 
Indonesia, Pattani Malay and English Phonetics and Phonology

Indonesian phonetics and Phonology

Vowels

$:([\mathrm{i}],[\mathrm{I}],[\mathrm{e}],[\varepsilon],[\mathrm{a}],[ə],[\mathrm{o}],[\mathrm{o}],[\mathrm{U}],[\mathrm{u}]$

(Marsono, 1999: 36)

Diphthongs $\quad$ :[aI], [oi], [aU] (Marsono, 1999: 51)

Consonants $\quad$ :b, c, d, f, g, h, j, k, l, m, n, p, q, r, s, t, v, w, x, y, z (Marsono, 1999:101).

\section{Pattani Malays Phonetics and Phonology}

Vowels

: they are 8 single non-nasalized vowels $/ \mathrm{i}, \mathrm{e}, \varepsilon, \dot{\mathrm{i}}, \mathrm{a}$, u, o, o/ and 4 simple nasalized vowels / غ́, ã, ũ, o/.

Diphthongs : : /ai, ae, ać, ao, au/

Consonants $\quad: / \mathrm{p}, \mathrm{b}, \mathrm{t}, \mathrm{d}, \mathrm{c}, \mathrm{J}, \mathrm{k}, \mathrm{g}, \mathrm{?}, \mathrm{s}, \mathrm{\gamma}, \mathrm{h}, \mathrm{m}, \mathrm{n}, \mathrm{n}, \mathrm{y}, \mathrm{r}, \mathrm{l}, \mathrm{w}, \mathrm{y}$, z/ (Yupho, 1989: 126-127).

\section{English Phonetics and Phonology}

Vowels : I, I, e, æ, p, v, u, ^, ə, i:, 3:, a:, o:, u: (Roach, 2000: 14-18)

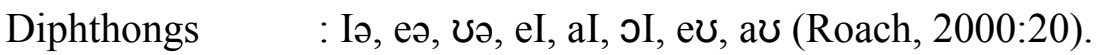

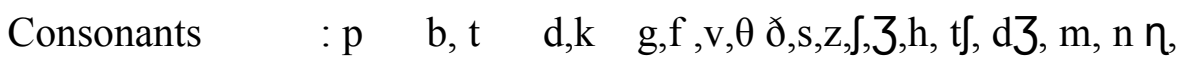
1, w, r, j (Roach (2000:52).

\section{Phonetic Rule of Pronouncing s/es Suffix}

If the end of the words is voiceless sound ( $p, t, k, f, \theta, h)$ it should be pronounced $/ \mathrm{s} /$. If the end of the words is voiced (p,t,k,f, b,d,g, v, ð,z, 3, $1, r, j, w, m, n, \eta$, sound, it should be pronounced $/ z /$. The last rule is if it 
The Differences between Thai and Indonesian Undergraduates in Pronouncing Plural Nouns and Third Singular Present Verbs due to Progressive Assimilation

is ended with /s, $\int, \mathrm{t} \int \mathrm{d} 3 /$ sounds, it should be pronounced /Iz/.

\section{Research Method}

This research used qualitative approach and the type is case study. According to Mackey and Gass (2005:171) defines case study as kind of research that aim to provide a holistic description of language learningor use within a specific population and setting. The data of the research is the pronunciation of s/es suffix in plural nouns and third singular present verbs by 4 Thailand and 4 Indonesian undergraduates of third semester students IAIN Salatiga 2015/2016. It was collected through interview and recording from June up to August. 4 Indonesian undergraduates are coded with symbol A, B, C, and D; and Thai undergraduates are coded with $\mathrm{P}, \mathrm{Q}, \mathrm{R}, \mathrm{S}$. All of respondents are interviewed based on some questions prepared by the writer and they are asked to read the list of words which consist of 30 plural nouns, 30 present verbs and a paragraph with s/es suffix in the end of the words. After collecting data, the writer analyze and compare the differences and similarities of Thai and Indonesian undergraduates of IAIN Salatiga in pronouncing plural nouns and third singular present verbs due to progressive assimilation. The writer also investigates the factors that influence the differences and similarities between two groups.

\section{Discussion}

\section{Interview of Thai Undergraduates}

According to Thai undergraduates, they learn English since they was in kindergarten class. English in Thailand is the foreign language. They have learned about pronunciation before but only the basic materials such as vocal, consonant both voiced and voiceless, and 
diphthongs. As interviewed, they do not know about the phonetic rule of s/es ending. They learn the pronunciation of s/es ending by hearing some dialogs from any sources such as internet or native speaker which they called 'learning by ear'.

Learning English in Indonesia make them face some difficulties because they have not known about Indonesian language (Bahasa) completely. When they did not know about the meaning of a certain word, they will not get a clear definition of the word through an explanation using Bahasa. Although there are some similarities of Pattani Malay and Indonesian language, but it is absolutely different. Because of its differences, it will influence the pronunciation include s/es ending.

\section{Indonesian Undergraduates}

According to Indonesian undergraduates, most of them learn English since they was in primary school. They do not know about the pronunciation rule of s/es ending, especially in plural noun and third singular verbs, because they never learn it before. In the previous schools, the teacher does not explain about the pronunciation/phonetic rule of s/es ending. The teacher only focuses on the grammatical rule of s/es ending and pronunciation is not considered as an important aspect.

According to them, native language will influence the pronunciation of target language, in this case English. Native language will cause different accent, so they assumed that Thai and Indonesian undergraduates will have different accent in speaking English. 
The Differences between Thai and Indonesian Undergraduates in Pronouncing Plural Nouns and Third Singular Present Verbs due to Progressive Assimilation

\section{Recording}

\section{Indonesian Phonetic Classification}

\begin{tabular}{|c|c|c|c|c|}
\hline No & Words & $\begin{array}{c}\text { Dictionary } \\
\text { Transcripti } \\
\text { on }\end{array}$ & Subject & Description \\
\hline 1 & Begins & /bI'gInz/ & $\mathrm{ABC} D$ & $\begin{array}{l}\text { Substitution of } / \mathrm{z} / \text { sound to be } / \mathrm{s} / \\
\text { sound }\end{array}$ \\
\hline 2 & Brushes & $/ \mathrm{br} \wedge \int \mathrm{Iz} /$ & B & $\begin{array}{l}\text { Substitution of /Iz/ sound with /os/ } \\
\text { sound }\end{array}$ \\
\hline 3 & Buys & /baIz/ & $\mathrm{ABCD}$ & Substitution of /z sound to be /s/ \\
\hline 4 & Catches & /kæt]Iz/ & $\mathrm{ABC}$ & Substitution of Iz sound to be 2 s sound \\
\hline 5 & Cries & $/ \mathrm{kraIz} /$ & ABCD & Substitution of $\mathrm{z}$ sound to be $\mathrm{s}$ sound \\
\hline 6 & Dances & /da:nsIz/ & $\mathrm{BC}$ & Substitution of Iz sound to be as sound \\
\hline 7 & Drinks & /drInks/ & - & - \\
\hline 8 & Eats & /i:ts/ & - & - \\
\hline 9 & Falls & /fo:lz/ & $\mathrm{BCD}$ & Substitution of $\mathrm{z}$ sound to be $\mathrm{s}$ sound \\
\hline 10 & Fixes & /fIksIz/ & - & - \\
\hline 11 & Flies & /flaIz/ & $\mathrm{ABCD}$ & Substitution of $\mathrm{z}$ sound to be $\mathrm{s}$ sound \\
\hline 12 & Kisses & /kIsIz/ & $\mathrm{AB}$ & Substitution of Iz sound to be as sound \\
\hline 13 & Lives & /livz/ & $\mathrm{ACD}$ & Substitution of $\mathrm{z}$ sound to $\mathrm{b}$ s sound \\
\hline 14 & Looks & /luks/ & - & - \\
\hline 15 & Opens & /’eupənz/ & $\mathrm{ABCD}$ & Substitution of $\mathrm{z}$ to be s sound \\
\hline 16 & Passes & /pa:sIz/ & $\mathrm{ABC}$ & Substitution of Iz sound to be 2 s sound \\
\hline 17 & Plays & /pleIz/ & $\mathrm{ABCD}$ & Substitution of $\mathrm{z}$ sound to be s sound. \\
\hline 18 & Puts & /puts/ & - & - \\
\hline 19 & Says & /seIz/ & ABCD & Substitution of $\mathrm{z}$ sound to be $\mathrm{s}$ sound \\
\hline 20 & Sees & /si:z/ & $\mathrm{ABCD}$ & Substitution of $\mathrm{z}$ sound to be s sound \\
\hline 21 & Sits & /sIts/ & - & - \\
\hline 22 & Stays & /steIz/ & $\mathrm{ABC}$ & Substitution of $\mathrm{z}$ sound to be s sound \\
\hline 23 & Stops & /stbps/ & - & - \\
\hline
\end{tabular}




\begin{tabular}{|c|c|c|c|c|}
\hline 24 & Takes & /teIks/ & - & - \\
\hline 25 & Tries & /traIz/ & $\mathrm{ABCD}$ & Substitution of $\mathrm{z}$ sound to be $\mathrm{s}$ sound \\
\hline 26 & Washes & /wDJIz/ & B & Substitution of Iz sound to be as sound \\
\hline 27 & Watches & /wDt]Iz/ & $\mathrm{AB}$ & Substitution of Iz sound to be as sound \\
\hline 28 & Waters & /wo:tərz/ & $\mathrm{ABCD}$ & Substitution of $\mathrm{z}$ sound to be $\mathrm{s}$ sound \\
\hline 29 & Wishes & /WI]Iz/ & $\mathrm{AB}$ & Substitution of Iz sound to be as sound \\
\hline 30 & Writes & /raIts/ & - & - \\
\hline \multicolumn{5}{|c|}{ NOUN } \\
\hline 1 & Animals & /’ænImlz/ & $\mathrm{ABCD}$ & Substitution of $\mathrm{z}$ sound to be $\mathrm{s}$ sound \\
\hline 2 & Apples & /’æplz/ & $\mathrm{ABC}$ & Substitution of $\mathrm{z}$ sound to be $\mathrm{s}$ sound \\
\hline 3 & Books & /buks/ & - & - \\
\hline 4 & Boys & /boIz/ & $\mathrm{ABC}$ & Substitution of $\mathrm{z}$ sound to be $\mathrm{s}$ sound \\
\hline 5 & Cars & /ka:rz/ & $\mathrm{ABCD}$ & Substitution of $\mathrm{z}$ sound to be $\mathrm{s}$ sound \\
\hline 6 & Cats & /kæts/ & - & - \\
\hline 7 & Cities & /'sItiz/ & $\mathrm{ABC}$ & \\
\hline 8 & Countries & /'k^ntriz/ & $\mathrm{ABCD}$ & Substitution of $\mathrm{z}$ sound to be s sound \\
\hline 9 & Dictionaries & /'drkJənriz/ & $\mathrm{ABCD}$ & Substitution of $\mathrm{z}$ sound to be $\mathrm{s}$ sound \\
\hline 10 & Dogs & /dogz/ & $\mathrm{ABC}$ & Substitution of $\mathrm{z}$ sound to be $\mathrm{s}$ sound \\
\hline 11 & Dolls & /dplz/ & $\mathrm{B}$ & Substitution of $\mathrm{z}$ sound to be $\mathrm{s}$ sound \\
\hline 12 & Eggs & /egz/ & $\mathrm{ABCD}$ & Substitution of $\mathrm{z}$ sound to be $\mathrm{s}$ sound \\
\hline 13 & Elephants & /'elıfənts/ & - & - \\
\hline 14 & Exercises & $\begin{array}{l}\text { /eksəsaIzIz } \\
/\end{array}$ & $\mathrm{BC}$ & Substitution of Iz sound to be əs sound \\
\hline 15 & Fishes & /fI]IZ/ & $\mathrm{BC}$ & Substitution of Iz sound to be əs sound \\
\hline 16 & Flowers & /'flauərz/ & $\mathrm{ABCD}$ & Substitution of $\mathrm{z}$ sound to be $\mathrm{s}$ sound \\
\hline 17 & Giraffes & /d3ə'ra:fs/ & $\mathrm{ABD}$ & Substitution of s sound to be as sound \\
\hline 18 & Girls & /g3:lz/ & $\mathrm{ABCD}$ & Substitution of $\mathrm{z}$ sound to be $\mathrm{s}$ sound \\
\hline 19 & Horses & /h৩:sIz/ & $\mathrm{BC}$ & Substitution of Iz sound to be as sound \\
\hline
\end{tabular}


The Differences between Thai and Indonesian Undergraduates in Pronouncing Plural Nouns and Third Singular Present Verbs due to Progressive Assimilation

\begin{tabular}{|c|c|c|c|c|}
\hline 20 & Houses & /hausIz/ & $\mathrm{BCD}$ & Substitution of Iz sound to be as sound \\
\hline 21 & Hats & /hæts/ & - & - \\
\hline 22 & Hotels & /hDtælz/ & $\mathrm{ABCD}$ & Substitution of $\mathrm{z}$ sound to be $\mathrm{s}$ sound \\
\hline 23 & Keys & /ki:z/ & $\mathrm{ABCD}$ & Substitution of $\mathrm{z}$ sound to be $\mathrm{s}$ sound \\
\hline 24 & Offices & /'DfIsIz/ & $\mathrm{AB}$ & Substitution of Iz sound to be as sound \\
\hline 25 & Oranges & /'DrInd3Iz & B & Substitution of Iz sound to be as sound \\
\hline 26 & Tables & /’teIblz/ & $\mathrm{ABCD}$ & Substitution of $\mathrm{z}$ sound to be $\mathrm{s}$ sound \\
\hline 27 & Teachers & /ti:t]ərz/ & $\mathrm{ABCD}$ & Substitution of $\mathrm{z}$ sound to be $\mathrm{s}$ sound \\
\hline 28 & Umbrellas & $\begin{array}{l}\text { /^m’breləz } \\
/\end{array}$ & $\mathrm{ABCD}$ & Substitution of $\mathrm{z}$ sound to be $\mathrm{s}$ sound \\
\hline 29 & Uncles & /’^yklz/ & $\mathrm{ABCD}$ & Substitution of $\mathrm{z}$ sound to be $\mathrm{s}$ sound \\
\hline 30 & Wolves & /wolfs/ & B & Substitution of s sound to be əs sound \\
\hline
\end{tabular}

WORDS IN PARAGRAPH

\begin{tabular}{|c|c|c|c|}
\hline Comes & $/ \mathrm{k} \wedge \mathrm{mz} /$ & $\mathrm{ABCD}$ & Substitution of $\mathrm{z}$ sound to be $\mathrm{s}$ sound \\
\hline Lives & /lIVz/ & $\mathrm{BCD}$ & Substitution of $\mathrm{z}$ sound to be $\mathrm{s}$ sound \\
\hline Teaches & /ti:tfIz/ & $\mathrm{BC}$ & Substitution of Iz sound to be as sound \\
\hline Likes & /laIks/ & - & - \\
\hline Walks & /wo:ks/ & - & - \\
\hline Arrives & /a’raIvz/ & $\mathrm{ACD}$ & Substitution of $\mathrm{z}$ sound to be $\mathrm{s}$ sound \\
\hline Enjoys & /In'd3כIz/ & $\mathrm{ABCD}$ & Substitution of $\mathrm{z}$ sound to be $\mathrm{s}$ sound \\
\hline Jobs & /d3obz/ & $\mathrm{ABC}$ & Substitution of $\mathrm{z}$ sound to be $\mathrm{s}$ sound \\
\hline Loves & $/ 1 \wedge v z /$ & $\mathrm{ABCD}$ & Substitution of $\mathrm{z}$ sound to be $\mathrm{s}$ sound \\
\hline Students & /stju:dnts/ & - & - \\
\hline Misses & /mIsIz/ & BCD & Substitution of Iz sound to be Is sound \\
\hline Gives & /gIVZ/ & B & Substitution of $\mathrm{z}$ sound to be $\mathrm{s}$ sound \\
\hline
\end{tabular}




\begin{tabular}{|c|c|c|c|}
\hline Asks & /a:sks/ & $\mathrm{BC}$ & Omission of s sound \\
\hline Questions & /'kwest「ənz/ & $\mathrm{ABCD}$ & Substitution of $\mathrm{z}$ sound to be $\mathrm{s}$ sound \\
\hline Corrects & /kə’rekts/ & - & - \\
\hline Speaks & /spi:ks/ & - & - \\
\hline Forgets & /fə'gets/ & - & - \\
\hline Names & /neImz/ & $\mathrm{ABCD}$ & Substitution of $\mathrm{z}$ sound to be $\mathrm{s}$ sound \\
\hline Finishes & /'fInIJIz/ & $\mathrm{ABC}$ & Substitution of Iz sound to be əs sound \\
\hline
\end{tabular}

\section{Thai Phonetic Classification}

\begin{tabular}{|c|c|c|c|c|}
\hline No & Words & $\begin{array}{c}\text { Dictionary } \\
\text { Transcription }\end{array}$ & Subject & Description \\
\hline 1 & Begins & /bI'gInz/ & PRS & Substitution of $\mathrm{z}$ sound to be $\mathrm{s}$ sound \\
\hline 2 & Brushes & $/ \mathrm{br} \wedge \int \mathrm{Iz} /$ & QRS & Omission of Iz sound \\
\hline 3 & Buys & /baIz/ & PQRS & Substitution of $\mathrm{z}$ sound to be $\mathrm{s}$ sound \\
\hline 4 & Catches & /kæt]Iz/ & $\mathrm{RS}$ & Omission of Iz sound \\
\hline 5 & Cries & $/ \mathrm{kraIz} /$ & PQRS & Substitution of $\mathrm{z}$ sound to be $\mathrm{s}$ sound \\
\hline 6 & Dances & /da:nsIz/ & PQRS & Omission of Iz sound \\
\hline 7 & Drinks & /drInks/ & & - \\
\hline 8 & Eats & /i:ts/ & & - \\
\hline 9 & Falls & /fo:lz/ & RS & Substitution of $\mathrm{z}$ sound to be $\mathrm{s}$ sound \\
\hline 10 & Fixes & /fIksIz/ & PS & $\begin{array}{l}\text { Substitution of IZ sound to be Is } \\
\text { sound }\end{array}$ \\
\hline 11 & Flies & /flaIz/ & PQRS & Substitution of $\mathrm{z}$ sound to be $\mathrm{s}$ sound \\
\hline 12 & Kisses & /kIsIz/ & QRS & $\begin{array}{l}\text { Substitution of Iz sound to be } 2 \text { s } \\
\text { sound }\end{array}$ \\
\hline 13 & Lives & /livz/ & QRS & Substitution of $\mathrm{z}$ sound to be $\mathrm{s}$ sound \\
\hline 14 & Looks & /lvks/ & & - \\
\hline 15 & Opens & /'euspənz/ & PQRS & Substitution of $\mathrm{z}$ sound to be $\mathrm{s}$ sound \\
\hline
\end{tabular}


The Differences between Thai and Indonesian Undergraduates in Pronouncing Plural Nouns and Third Singular Present Verbs due to Progressive Assimilation

\begin{tabular}{|c|c|c|c|c|}
\hline 16 & Passes & /pa:sIz/ & $\mathrm{RS}$ & Omission of Iz sound \\
\hline 17 & Plays & /pleIz/ & PQRS & Substitution of $\mathrm{z}$ sound to be $\mathrm{s}$ sound \\
\hline 18 & Puts & /puts/ & - & - \\
\hline 19 & Says & /seIz/ & $\mathrm{RS}$ & Substitution of $\mathrm{z}$ sound to be $\mathrm{s}$ sound \\
\hline 20 & Sees & /si:z/ & $\mathrm{S}$ & Omission of $\mathrm{s}$ sound \\
\hline 21 & Sits & /sIts/ & - & - \\
\hline 22 & Stays & /steIz/ & PRS & Substitution of $\mathrm{z}$ sound to be $\mathrm{s}$ sound \\
\hline 23 & Stops & /stDps/ & - & - \\
\hline 24 & Takes & /teIks/ & - & - \\
\hline 25 & Tries & $/$ traIz/ & PQR & Substitution of $\mathrm{z}$ sound to be $\mathrm{s}$ sound \\
\hline 26 & Washes & /wDJIz/ & QRS & $\begin{array}{l}\text { Substitution of Iz sound to be as } \\
\text { sound }\end{array}$ \\
\hline 27 & Watches & /wDt[Iz/ & PS & $\begin{array}{l}\text { Substitution of Iz sound to be } \partial \mathrm{Z} \\
\text { sound }\end{array}$ \\
\hline 28 & Waters & /wo:tərz/ & PQRS & Substitution of $\mathrm{z}$ sound to be $\mathrm{s}$ sound \\
\hline 29 & Wishes & /WI]Iz/ & PQR & $\begin{array}{l}\text { Substitution of Iz sound to be as } \\
\text { sound }\end{array}$ \\
\hline 30 & Writes & /raIts/ & - & - \\
\hline \multicolumn{5}{|c|}{ NOUN } \\
\hline 1 & Animals & /’ænImlz/ & PQRS & Substitution of $\mathrm{z}$ sound to be $\mathrm{s}$ sound \\
\hline 2 & Apples & /’æplz/ & $\mathrm{P}$ & Substitution of $\mathrm{z}$ sound to be $\mathrm{s}$ sound \\
\hline 3 & Books & /buks/ & - & - \\
\hline 4 & Boys & /boIz/ & PQRS & Substitution of $\mathrm{z}$ sound to be $\mathrm{s}$ sound \\
\hline 5 & Cars & /ka:rz/ & PQRS & Substitution of $\mathrm{z}$ sound to be $\mathrm{s}$ sound \\
\hline 6 & Cats & /kæts/ & - & - \\
\hline 7 & Cities & /'sItiz/ & PQR & Substitution of $\mathrm{z}$ sound to be $\mathrm{s}$ sound \\
\hline 8 & Countries & /'k^ntriz/ & PQR & Substitution of $\mathrm{z}$ sound to be $\mathrm{s}$ sound \\
\hline 9 & $\begin{array}{l}\text { Dictionarie } \\
\mathrm{s}\end{array}$ & /’dIkJənriz/ & PQRS & Substitution of $\mathrm{z}$ sound to be $\mathrm{s}$ sound \\
\hline
\end{tabular}




\begin{tabular}{|c|c|c|c|c|}
\hline 10 & Dogs & /dogz/ & PQRS & Substitution of $z$ sound to be s sound \\
\hline 11 & Dolls & /dplz/ & PR & Substitution of $\mathrm{z}$ sound to be $\mathrm{s}$ sound \\
\hline 12 & Eggs & /egz/ & PQS & Substitution of $\mathrm{z}$ sound to be $\mathrm{s}$ sound \\
\hline 13 & Elephants & /'elıfənts/ & - & - \\
\hline 14 & Exercises & /eksəsaIzIz/ & PRS & Omission of Iz sound \\
\hline 15 & Fishes & /fIJIz/ & PQRS & Omission of Iz sound \\
\hline 16 & Flowers & /'flavorz/ & PQRS & Substitution of $\mathrm{z}$ sound to be $\mathrm{s}$ sound \\
\hline 17 & Giraffes & /d3ə'ra:fs/ & PQRS & $\begin{array}{l}\text { Substitution of } \mathrm{s} \text { sound to be as } \\
\text { sound }\end{array}$ \\
\hline 18 & Girls & /g3:lz/ & PQRS & Substitution of $\mathrm{z}$ sound to be $\mathrm{s}$ sound \\
\hline 19 & Horses & /ho:sIz/ & PQRS & Omission of Iz sound \\
\hline 20 & Houses & /havsIz/ & PQRS & Omission of Iz sound \\
\hline 21 & Hats & /hæts/ & - & - \\
\hline 22 & Hotels & /hotælz/ & PQR & Substitution of $\mathrm{z}$ sound to be s sound \\
\hline 23 & Keys & /ki:z/ & PQR & Substitution of $\mathrm{z}$ sound to be s sound \\
\hline 24 & Offices & /'DfIsIz/ & PQR & Omission of Iz sound \\
\hline 25 & Oranges & /'DrInd3Iz/ & QR & $\begin{array}{l}\text { Substitution of IZ sound to be } \mathrm{s} \\
\text { sound }\end{array}$ \\
\hline 26 & Tables & /'teIblz/ & PQRS & Substitution of $z$ sound to be s sound \\
\hline 27 & Teachers & /ti:t〕ərz/ & PQR & Substitution of $\mathrm{z}$ sound to be $\mathrm{s}$ sound \\
\hline 28 & Umbrellas & /^m’breləz/ & QRS & Omission of $\mathrm{z}$ sound \\
\hline 29 & Uncles & /'^yklz/ & QRS & Substitution of $\mathrm{z}$ sound to be $\mathrm{s}$ sound \\
\hline 30 & Wolves & /wolfs/ & PQ & Substitution of s sound to be $2 \mathrm{~s}$ \\
\hline \multicolumn{5}{|c|}{ Paragraph } \\
\hline 1 & Comes & $/ \mathrm{k} \wedge \mathrm{mz} /$ & PQS & Omission of $\mathrm{z}$ sound \\
\hline 2 & Lives & /livz/ & QRS & Omission of $\mathrm{z}$ sound \\
\hline 3 & Teaches & /ti:tlIz/ & $\mathrm{R}$ & $\begin{array}{l}\text { Substitution of Iz sound to be } 2 \mathrm{~s} \\
\text { sound }\end{array}$ \\
\hline 4 & Likes & /laIks/ & $\mathrm{RS}$ & Omission of $\mathrm{s}$ sound \\
\hline
\end{tabular}


The Differences between Thai and Indonesian Undergraduates in Pronouncing Plural Nouns and Third Singular Present Verbs due to Progressive Assimilation

\begin{tabular}{|c|c|c|c|c|}
\hline 5 & Walks & /wo:ks/ & $\mathrm{S}$ & Omission of $\mathrm{s}$ sound \\
\hline 6 & Arrives & /ə’raIvz/ & PS & Substitution of $\mathrm{z}$ sound to be $\mathrm{s}$ sound \\
\hline 7 & Enjoys & /In'd3JIZ/ & PQR & Substitution of $\mathrm{z}$ sound to be $\mathrm{s}$ sound \\
\hline 8 & Jobs & /d3Dbz/ & PQS & Substitution of $\mathrm{z}$ sound to be s sound \\
\hline 9 & Loves & $/ \operatorname{lnvz/}$ & PQR & Substitution of $\mathrm{z}$ sound to be s sound \\
\hline 10 & Students & /stju:dnts/ & - & - \\
\hline 11 & Misses & /mIsIz/ & PQRS & $\begin{array}{l}\text { Substitution of IZ sound to be Is } \\
\text { sound }\end{array}$ \\
\hline 12 & Gives & /gIVZ/ & PQS & Substitution of $\mathrm{z}$ sound to be s sound \\
\hline 13 & Asks & /a:sks/ & PQR & Omission of s sound \\
\hline 14 & Questions & /'kwest]ənz/ & PQ & Substitution of $\mathrm{z}$ sound to be $\mathrm{s}$ sound \\
\hline 15 & Corrects & /kə'rekts/ & QR & Omission of s sound \\
\hline 16 & Speaks & /spi:ks/ & PR & Omission of s sound \\
\hline 17 & Forgets & /fə’'gets/ & QR & Omission of s sound \\
\hline 18 & Names & /neImz/ & PR & Omission of $\mathrm{z}$ sound \\
\hline 19 & Finishes & /'fInIJIz/ & PQRS & Omission of Iz sound \\
\hline
\end{tabular}

Thai and Indonesian Phonetic Differences

\begin{tabular}{|c|c|c|c|}
\hline No & $\begin{array}{l}\text { Categories of } \\
\text { Differences }\end{array}$ & $\begin{array}{c}\text { Thai } \\
\text { Undergraduates }\end{array}$ & $\begin{array}{c}\text { Indonesian } \\
\text { Undergraduates }\end{array}$ \\
\hline 1 & $\begin{array}{l}\text { Substitution of } \mathrm{z} \\
\text { sound to be s sound }\end{array}$ & $=$ & $=$ \\
\hline 2 & $\begin{array}{l}\text { Substitution of Iz } \\
\text { sound to be Is sound }\end{array}$ & - & + \\
\hline 3 & $\begin{array}{l}\text { Substitution of } \\
\text { /Iz/ sound to be } \\
\text { sound }\end{array}$ & - & + \\
\hline 4 & $\begin{array}{l}\text { Substitution of } \mathrm{s} / \mathrm{z} \\
\text { sound to be əs sound. }\end{array}$ & $=$ & $=$ \\
\hline 5 & $\begin{array}{l}\text { Substitution of Iz } \\
\text { sound to be s sound }\end{array}$ & + & - \\
\hline 6 & $\begin{array}{l}\text { Omission of } \mathrm{s} / \mathrm{z} \\
\text { sound }\end{array}$ & + & - \\
\hline
\end{tabular}




\begin{tabular}{|l|c|c|c|}
\hline 7 & $\begin{array}{c}\text { Omission of Iz } \\
\text { sound. }\end{array}$ & + & - \\
\hline Note: & + more words are pronounced through this way. \\
& & \\
& & Less words are pronounced through this way. \\
& $=$ Words pronounced this way are same
\end{tabular}

\section{Substitution of $/ z /$ sound to be $/ \mathrm{s} /$ sound}

Based on the research, both Thai and Indonesian undergraduates pronounce most of the word by substitute /z/ sound to be /s/ sound. The word such as begins, buys, cries, falls, lives, animals, apples which should be pronounce by adding / $\mathrm{z} /$ sound are pronounced as /s/ sound.

One of the reason why they substitute /z/ sound to be /s/ sound is they do not know about the phonetic rule of the pronunciation of s/es ending. Although both $/ \mathrm{s} /$ and $/ \mathrm{z} /$ exist in both Thai and Indonesian language, but $/ \mathrm{z} /$ sound is rarely being used in the end of the word. Because they do not know the rule, it is more comfortable to use /s/ sound than $/ z /$ sound.

\section{Substitution of Iz sound to be Is sound}

Compared with Thai undergraduates, Indonesian undergraduates more often pronounce the list of words by substitute /Iz/ sound to be /Is/ sound than Thai undergraduates. This occurs related to the fact that Bahasa Indonesia has many loanwords, one of them are from the Dutch because of the Dutch colonialism from $19^{\text {th }}$ centuries. Suffix of Dutch vocabulary such as -ical, -isch; in vocabulary of Bahasa Indonesia it becomes $-i s$ for example:

Economical, economisch to be ekonomis, practical, practisch to be praktis, logical, logisch to be logis. Not only loanwords from Dutch, 
loanwords from English also influence the pronunciation of the word by substitute /Iz/ sound to be Is sound for example publicist to be publisis, guitarist to be gitaris, pianist to be pianis (Pusbadepdiknas, 2000:45).

Based on this explanation, there is a tendency to pronounce the word by /Is/ than /Iz/ because in the vocabulary of Bahasa Indonesia, many of them have suffix/Is/ sound.

\section{Substitution of /Iz/ sound to be /os/ sound}

Indonesian undergraduates pronounce more words with substitution of /IZ/ sound to be əs sound than Thai undergraduates. According to the phonetic rule, the word brushes, catches, dances, kisses, passes, washes, watches, wishes, exercises, finishes, horses, houses, offices, oranges, teaches, finishes; the es ending should be pronounced by /Iz/. As the result of the research, Indonesian undergraduates substitute the /Iz/ sound to be /os/ sound. Thai undergraduates do, but they are fewer than Indonesian undergraduates.

\section{Substitution of s/z sound to be os sound}

Based on the result of the research, the substitution of $\mathrm{s} / \mathrm{z}$ sound to be əs sound in pronouncing third singular verbs and plural nouns between Thai and Indonesian undergraduates are balance. There are two words which are pronounced by substitute $s / z$ sound for both Thai and Indonesian undergraduates. Pronunciation of third singular verbs and plural nouns show that English allows consonant cluster. This type of consonant cluster is difficult to produce for both Thai and Indonesian undergraduates.

Some respondents from both Thailand and Indonesia sometimes fail to produce the words correctly. As the result of the research, Thai and 
Indonesian undergraduates pronounce 'giraffes'/d3ə'ra:fs/ and 'wolves'/wひlfs/ by substitute/s/ sound to be /əs/, so they add/a/ sound before /s/ sound to cope the difficulties.

\section{Substitution of Iz sound to be s sound}

In pronouncing the word 'oranges'; two of Thai undergraduates (Q and R) substitute Iz sound to be s sound. According to the phonetic rule of third singular verb and plural noun, 'oranges' should be pronounced /'DrInd3Iz/, but Thai undergraduates pronounce it as /'DrInd3s/. Although a little difficult to pronounce consonant cluster of English words, they try to repeat the pronunciation of oranges /'DrInd3Iz/ by /'DrInd3s/ because they do not know about pronunciation/phonetic rule of s/es ending.

\section{Omission of s/z sound}

In pronouncing the provided words, Thai undergraduates omit $\mathrm{s} / \mathrm{z}$ sound in some words like sees, umbrellas, comes, lives, likes, walks, asks, corrects, speaks, forgets and names. Indonesian undergraduates do so, but only a specific word such as 'asks'. It is too difficult for Indonesian undergraduates to pronounce a consonant cluster which consists of three consonant and a vowel in beginning.

\section{Omission of Iz sound}

The omission of Iz sound occur when Thai undergraduates pronounces the list of words, especially in paragraph. Most of third singular second verbs and plural in paragraph are pronounced by Thai undergraduates by omitting IZ sound. As explained in chapter II, in Pattani Malays / $z /$ sound is found in most of loan words. It is rarely found 
in the root of Pattani Malay words. Most of Pattani words are pronounced with vocal in the end of the words. The omission of IZ sound does not happen to Indonesian undergraduates.

\section{Conclusion}

The differences of Thai and Indonesian undergraduates in pronouncing third singular verbs and plural nouns are:

More Indonesian undergraduates pronounce third singular verbs and plural nouns by substitute /IZ/ sound to be Is sound as in fishes, watches, and wishes. Indonesian undergraduates pronounce more verbs and plural nouns are pronounced by substitute /IZ/ sound to be əs sound as in brushes, catches, dances, kisses, passes, washes, watches, wishes, exercises, finishes, horses, houses, offices, oranges, teaches, finishes. Thailand undergraduates pronounce more third singular verbs and plural noun by omitting plural maker $[\mathrm{s}, \mathrm{z}, \mathrm{Iz}]$ sound. For Indonesian undergraduates, it only happens in the word 'asks' because it is too difficult to pronounce consonant cluster of this word.

The similarities of Thai and Indonesian undergraduates in pronouncing third singular verbs and plural nouns are: Both Thai and Indonesian undergraduates pronounce many vocabularies (third singular verbs and plural noun) by substitute $\mathrm{z}$ sound to be s sound because $\mathrm{z}$ sound is rarely pronounced in their native language. Both Thai and Indonesian undergraduates pronounce many vocabularies (third singular verbs and plural noun) by substitute $[\mathrm{s} / \mathrm{z}]$ sound to be /os/. There is a tendency of both Thai and Indonesian undergraduates to add /ə/ sound before $/ \mathrm{s} /$ or $/ \mathrm{z} /$ sound because suffix consonant clusters are difficult to pronounce, so to cope with this both Thai and Indonesian undergraduates 
add /a/ sound before $\mathrm{s} / \mathrm{z}$ sound.

Factors that influence the differences of Thai and Indonesian undergraduates of IAIN Salatiga in pronouncing plural nouns and third singular verbs due to progressive assimilation are:

(1) Geographic dialects. According to Kreidler (2004:2), how much people contact with other speakers of the language and what influence there has been from speakers of other language will create the differences. Because Thai undergraduates does not contact frequently with other speaker, they have several differences in pronouncing English words from Indonesian undergraduates. (2) Native language. Native language of Thai and Indonesian undergraduates will influence the pronunciation of English third singular verbs and plural nouns. Thai undergraduates find difficulties in learning English in Indonesia, because they also have to learn Bahasa Indonesia to understand the material in the class, and it will influence the pronunciation. 


\section{References}

Frank, Marcella. (1972). Modern English: A Practical Reference Guide.

New Jersey: Prentice Hall-inc

Hamann, C.. \&Schmitz, C.(2005). Phonetics and Phonology: Reader for

First Year English Linguistics. Oldernburg: University of Oldenburg Press.

Lodge, Ken. 2009. A Critical Introduction to Phonetics. New York:

Continuum International Publishing Group.

Lorenz, Gunter.2009. English Phonetics Theory: BA Course (British English). Pdf. Retrieved from www.pdfsearchengine.org

Mackey, Alison, \& Gass, M. Susan. 2005. Second Language Research:

Methodology and Design. London: Lawrence Erlbaum Associates Publisher

Marsono. 1999. Fonetik. Yogyakarta: Gadjah Mada University Press.

McMahon, April. 2002. An Introduction to English Phonology. Edinburgh: Edinburgh University Press.

Pusbadepdiknas. 2000. Pedoman Umum Ejaan Bahasa Indonesia yang Disempurnakan. Pdf. Retrieved from www.pdfsearchengine.org.

Ramelan. (2003). English Phonetics. Semarang : UPT Unnes Press

Roach, Peter. 2000. English Phonetics and Phonology: A Practical Course. Cambridge: Cambridge University Press.

Yupho, Nawanit. 1989. Consonant Clusters and Stress Rules in Pattani Malay. Mon Khmer Studies. Pdf. Retrieved from www.pdfsearchengine .org. 